\title{
PREDICTION OF BIOMASS OF SPOTTED SARDINE (Amblygaster sirm) IN THE JAVA SEA
}

\author{
Suherman Banon Atmaja*) and Bambang Sadhotomo*
}

\begin{abstract}
Biomass of spotted sardine (Amblygaster sirm) has been predicted using biomass dynamic model and cohort analysis. These methods can predict behaviour biomass to impact of exploitation. A biomass dynamic can be used to explain how biomass responds to fishing pressure, for example, reduction of catch by quota, while relationship biomass of cohort analysis with effort can be used to explain how biomass responds to reduction of effort. Time series data used in modelling (1976 to 2004), the results of biomass dynamic model showed that biomass tend to recovery after 1994, when the catch has declined. On the contrary, length cohort analysis showed a declining trend since 1994. If effort is reduced around $10 \%$ to $20 \%$ of effort in 2004 , it could result to the increasing biomass of about 1,5 to 2,5 times higher than biomass 2004 , respectively. The size of biomass from Gompertz $\left(B_{M S Y}=24,200\right.$ tons) was higher than the results of cohort analysis $\left(B_{M S Y}=21,600\right.$ tons).
\end{abstract}

\section{KEYWORDS:}

\section{INTRODUCTION}

The siro, spotted sardine (Amblygaster sirm) is one of main pelagic fish in the Java Sea. This species is grouped into the group of fish, which like oceanic habitat (salinity habitat $>33$ per mil) (Sadhotomo \& Durand, 1997) and comprises around $10 \%$ of average annual catches of purse seiner during the period of 1977 to 2004. The landing increased significantly since the fishing grounds have been extended eastward. The monthly landings peaked obviously from December to February (Atmaja \& Sadhatomo, 2000).

The catch of spotted sardine was dominated by size 13 to $19 \mathrm{~cm}$ (FL) and more than $90 \%$ of the individuals caught by purse seiners were immature fish. The fish that have reached ripe stage leave the fishery and are not vulnerable to the seine net. The broodstocks were incidental caught in the purse seine fishery. The monthly development of GSI indicated that only single peak occurred in February and June, and to spawn along the continental slope of eastern part of the Java Sea (Atmaja \& Sadhatomo, 1997; Sadhotomo, 1998). Length at first maturity was $18.6 \mathrm{~cm}$ (FL) and the size of 17.5 to $20.5 \mathrm{~cm}$ (FL) have the batch fecundity with ranges of 15 to 24 thousands eggs (Atmaja et al., 1995). Average size of fish remained relatively unchanged during one decade (1983 to 1992) (Dwiponggo et al., 1986; Atmaja \& Nugroho, 1995; Sadhotomo, 1998). Conand (1991) concluded that this species was a short lifespan, the fish usually die before the second year, but some individuals can reach a second spawning season.

Together with the increase in the number of large vessels, there was a simultaneous increase in the engine capacity of the vessels and change main fishing tactic (spotlight replaced by fish aggregating device). The increasing fishing capacity has led to the changes in efficiency of fishing gear. The catchability coefficient (q) has risen about 6 times (Atmaja \& Nugroho, 2006a) and the diminution of small pelagic fish biomass reached $66 \%$ (Atmaja \& Nugroho, 2006b). In recent (2002 to 2004) years, the catch of purse seiners had drastically declined and changes in species composition on the eastern part of Java Sea, especially the increase in landing of leather jacket (Aluterus monoceros) when the peak season of scads, pronidea signal of the unhealthy status of pelagic fishery (Atmaja \& Nugroho, 2005). A theoretical perspective suggests that the fishery has to be managed through reduction in effort or harvest levels of individual fishermen (Clark \& Munro, 1979 in Wiratno et al., 1993).

Fish stocks are commonly estimated by performing one or more methods of the following three categories of approaches. The first one is direct method that usually applies acoustics data estimate. The second approach is the global or surplus production model. All of the family of this model at least needs catch and effort data with steady state equilibrium assumption underlying the model. Some extension of this approach, called as Climprod developed by Fréon (1986) includes 
environmental variability in the analysis as additional factor. The last approach is age base model. It is due to Beverton \& Holt (1957) who modelled the populations change with time varies in deterministic or mathematical equations. Another age based method is virtual population analysis that is a procedure for determining number of individuals based on catch at age data. Hilborn \& Walters (1992) stated that two alternative methods for assessing dynamic response of fish population to exploitation: biomass dynamic models and age structured models. Historically, biomass dynamic models have been the second choice used only when age structured data were unavailable. Each of these models has its own advantages and disadvantages depending on the situation in which it is applied.

This study is aimed to predict a biomass dynamic of spotted sardine ( $A$. sirm) and a possible impact of the change of fishing pattern on pelagic stock. We applied biomass dynamic models (variation of surplus production) and cohort analysis by assuming that no declining fish size. Both analyses assume that the stock of spotted sardine is in a steady state condition, i.e., that mortality and growth parameters and recruitment have been more or less constant in 1992.

\section{MATERIALS AND METHODS}

The pelagic fisheries in the Java Sea consist of different types of fishing gear having different selectivity by species and size. However, the semi industrial purse seine contribute more than $60 \%$ of Decapterus and $A$. sirm to the total landing of the same taxonomic group in the Java Sea area (included south of Kalimantan). For this reason, we assume that the catch data are coming from the same population and no other fishery (except of the Javanese fishery) exploits the same stock (Sadhotomo, 1998).

Catch of A. sirm and effort data were collected from semi industrial purse seiner during periods of 1976 until 2004, with the fishing base at Pekalongan and Juwana. In fisheries statistics, landings of spotted sardine are recorded as commercial category lemuru. However, in the field, lemuru (Sardinella lemuru) only caught by purse seiner when the fleets were operated in Kangean Island waters and total landing of this species do not reach $10 \%$ of category lemuru.

\section{Gompertz Growth Model}

The general structure of surplus production model is given by the following equation:
Biomass at $t+1=$ Biomass at $t+$ Production-

Natural Mortality .............................. (1

The term surplus production is used to represent the difference between production and natural mortality or $F(B)$. Several types of surplus production model exist that describe the relationship between stock (biomass) and production. One of these models employees the Gompertz growth function to analyse surplus production, with assuming that catch is a function of size of the stock and effort or catch per unit of effort is proportional with biomass (Hilborn \& Walters, 1992 in Fauzi, 1999), the dynamic of stock is then written as:

$$
\begin{aligned}
& F(B)=\partial B / \partial t=r B^{*} L N(B, B)-q B E \ldots \ldots \ldots \ldots \ldots \ldots \ldots \ldots \ldots \ldots \ldots \ldots \ldots \ldots \ldots \ldots \ldots \ldots \ldots \ldots \ldots \ldots \ldots \ldots \\
& B_{t+1}=B_{t}+F(B)-C \ldots \ldots \ldots \ldots \ldots
\end{aligned}
$$

Estimates of parameters $r, q$, and $B_{\infty}$ in equation (2) seperately applied procedure (Clarke et al., 1992):

$$
\operatorname{Ln}\left(U_{t+1}\right)=2 r /(2+r) \quad \operatorname{Ln} \quad\left(q \quad B_{n}\right)+(2-r) /(2+r) \text { in }\left(U_{t}\right)-q /(2+r)
$$

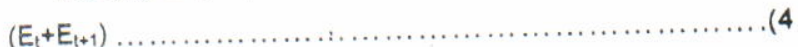

$$
\text { Or } Y=\beta_{0}+\beta_{1} X_{1}-\beta_{2} X_{2} \ldots \ldots \ldots \ldots \ldots \ldots \ldots \ldots \ldots \ldots \ldots \ldots \ldots \ldots \ldots
$$

A type surplus production model under assumption of Gompertz growth was developed by Fox (1975) in Fauzi (1999), this equation can be written in a familiar regression form as follow:

$$
C=q B_{\infty} E^{\star} E X P-\left(q / r^{\star} E\right) \text { or } C / E=\operatorname{Ln} q B_{\infty}
$$

$-(q / r) E$

$$
E_{M S Y}=r / q, \quad C_{M S Y}=r^{*} B_{\infty}{ }^{*} \operatorname{EXP}(-1) \text { and } B_{M S Y}=B_{*}{ }^{*} E X P(-1)=
$$

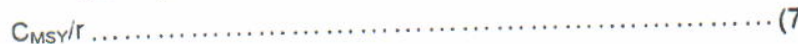

where

$$
\begin{aligned}
& r=\text { intrinsic growth rate of fish population } \\
& B_{\infty}=\text { environmental carrying capacity } \\
& q=\text { the catchability coefficient } \\
& E=\text { effort } \\
& B=\text { biomass } \\
& U=\text { catch per unit effort } \\
& T=\text { year }
\end{aligned}
$$

\section{Length Cohort Analysis}

Yearly basis catch at given class of age may be used to estimate population parameter, biomass, etc. This method provides an estimate of original number of individual of a year class being based on number of removal from that year class 
throughout its life. Pope (1972) developed a simple approximation to virtual population technique. The basic procedure for this method then was called as cohort analysis. The method uses common deterministic assumption, that within any one age group the decline in number with time variable follows an exponential decay function that can be expressed as:

$$
\mathrm{N}_{\mathrm{t}+1}=\mathrm{N}_{\mathrm{t}} \mathrm{e}^{-\mathrm{Z}}
$$

\section{where:}

$$
\begin{aligned}
N_{t+1}= & \text { number in the sea at age } t+1 \\
Z= & \text { instantaneous total mortality (in } \\
& \text { exponential basis }
\end{aligned}
$$

In cohort analysis the exponential curve within any age group is replaced by a step function which is based on the following assumptions:

1. The whole catch for that age group is taken at middle of age interval.

2. Natural loss is constant through all age (instantaneous natural mortality, $\mathrm{M}$ is constant).

The two basic formulae for this analysis are (Pope, 1972):

$$
\begin{aligned}
& N_{t}=N_{t+\Delta t} e^{M \Delta t}+C_{t} e^{M \Delta t / 2}=\left(C_{t}+N_{t+\Delta t} e^{M \Delta t / 2}\right) e^{M \Delta t / 2} . . \\
& C_{t}=N_{t}\left[1-e^{-\left(F_{t}+M\right)}\right] \ldots \ldots \ldots \ldots \ldots \ldots \ldots \ldots \ldots \ldots \ldots \ldots \ldots \ldots \ldots \ldots \ldots \ldots \ldots
\end{aligned}
$$

where:

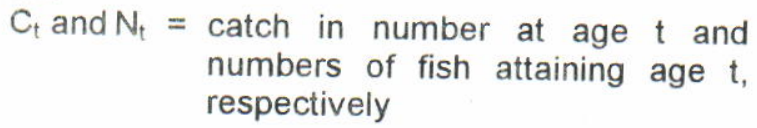

Jones' length cohort analysis (Jones, 1981) is based on the extension of Pope's cohort analysis formula to time variable interval. Following Jones $(1964 ; 1981)$, the derivation can be simply summarized as follow.

Rearrangement the position of term of von Bertalanffy equation results an expression that enable us to convert length to age:

$$
t=t_{0}-1 / K \ln \left(1-\dot{L} / L_{\infty}\right)
$$

The age difference corresponds to length interval or time required to grow from $L_{1}$ to $L_{2}$ is therefore simply written as:

$$
\Delta t=t_{2}-t_{1}=(1 / K) \text { In }\left(\left(L_{\infty}-L_{1}\right) /\left(L_{\infty}-L_{2}\right)\right)
$$

Assuming von Bertalanffy growth, this expression can be used in conjunction with Pope's basic cohort analysis formula. Substitution this expression into above basic formula results the following equation:

$$
N_{1}=\left(N_{2} X_{L}+C_{1,2}\right) X_{L}
$$

where $N_{1}$ and $N_{2}$ represents numbers in the sea at length $L_{1}$ and $L_{2}$ respectively, $C_{1,2}$ denote the number of fish captured in the interval $L_{1}$ and $L_{2}$, and $X_{L}$ is given by:

$$
X_{L}=\{\}^{M / 2 K}
$$

Based on the steady state at 1992, calculation of the biomass can be performed by converting to weight unit (length-weight relationship). Assumption there no unchanged the size of fish and structure of catch at length, biomass after 1992 can be easily computed by the following expression:

$$
\mathrm{B}_{92}=\Sigma^{\star} \text { a } \mathrm{L}^{\mathrm{b}}
$$

$$
\mathrm{B}_{\mathrm{t}+1}=\left(\mathrm{C}_{\mathrm{t}+1} / \mathrm{C}_{92}\right)^{\star} \mathrm{B}_{92}
$$

where $N_{1}$ and $N_{2}$ represents numbers in the sea at length $L$ and $L+\Delta L$ respectively, $B_{92}$ is biomass at 1992, $B_{t+1}$ is biomass after 1992, $C_{92}$ is catch at $1992, C_{t+1}$ is catch after $1992, Z$ is total mortality, a and $b$ is coefficient of length-weight relationship.

We used catch at length data of spotted sardine (A. sirm) and natural mortally was ranged from 1 to 2,3 year $^{-1}$ from Potier (1998), and estimation of growth (Table 1) from Sadhotomo (1998).

Table 1. Estimates values of growth parameters of spotted sardine (A. sirm) computed using ELEFAN

\begin{tabular}{ccc}
\hline Years & FL $\infty(\mathbf{c m})$ & $K_{\left(\text {year }^{-1}\right)}$ \\
\hline $1991-1992$ & 25.5 & 1 \\
& 26.0 & 1,1 \\
$1992-1993$ & 26,0 & 0,825 \\
$1993-1994$ & 26,25 & 0,65 \\
& 25,5 & 0,8 \\
\hline 1994-1995 & 25,25 & 0,65 \\
\hline Average & $\mathbf{2 5 , 7 5}$ & $\mathbf{0 , 8 4}$
\end{tabular}




\section{RESULTS AND DISCUSSION}

\section{Biomass Dynamic}

The catch and effort data of small pelagic species caught between 1976 and 2004 in the Java Sea was collected from semi industry of purse seiner where fishing base at Pekalongan and Juwana. The development of spotted sardine production in Pekalongan and Juwana was fluctuated, in 1976 until 1983 the spotted sardine production had increased 53 times, it could represent up to $20 \%$ of the purse seiner's catch. From 1983 and until 1988 the spotted sardine production was fluctuated and decreased a lot before increasing again sharply in 1992, and after that it stabilized. The spotted sardine production appears to be in declining trend. While the effort of purse seiners steadily increase (Figure 1a), and the catch per unit of effort decreased drastically (Figure ib).

Other constraint on the application of this method is related to the data acquisition in the official level. Until recent year there is no reliable statistical data available from the provinces out side the of Central Java Province. The basic system of statistical data collection is the same for all provinces but the tradition of data recording is really different. Citing from the report of Directorate General of Fisheries may arrive at substantial biases, as the tendency of an optimistic increase of landing at certain level (i.e. around 4 to $10 \%$ per year) whatsoever the condition of the fisheries. The spotted sardine production extracted from national statistical data of Directorate General of Fisheries showed an increasing trend (Figure 2). For this reason, we only used the catch effort data were coming from the semi industries of purse seine fishery landing in the main fishery harbour in the north coast of Java, especially Pekalongan and Juana Landing Place.

Figure 3 shows that the biomass tends to recovery after 1994, even when the catch has declined. Increasing biomass was not designed by reduction in catch levels or in effort. It ought to be continuously decreasing if based on assumption that catch per unit effort is proportional to biomass or fishing mortality is proportional to effort $(F=q E)$. The previous studies indicated that recovery stock was pseudo. Based on fishing mortality and effort readjusted through $F=q^{\star} E$ proved that diminution of biomass of scads (Decapterus macrosoma and $D$. russelli) reached $75 \%$ from initially biomass (Atmaja, 2006).

\section{Cohort analysis}

In the landings, individuals species of $A$. sirm range from 7,5 to $22,5 \mathrm{~cm}(F L)$. However, most of the catch consists of $98 \%$ of fish measuring

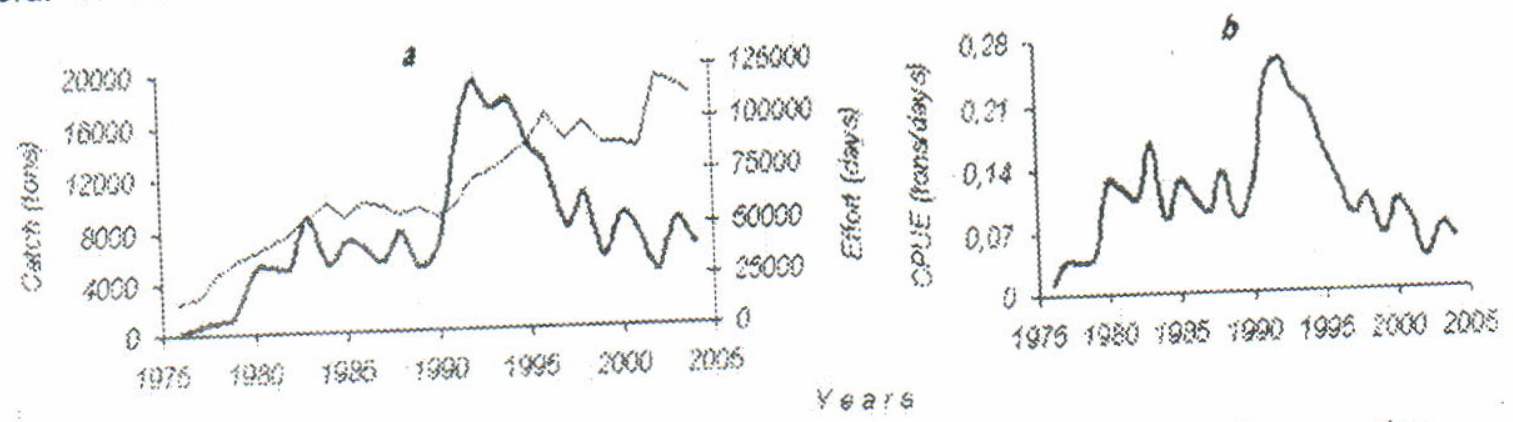

Figure 1. The development of spotted sardine production and effort of purse seine.

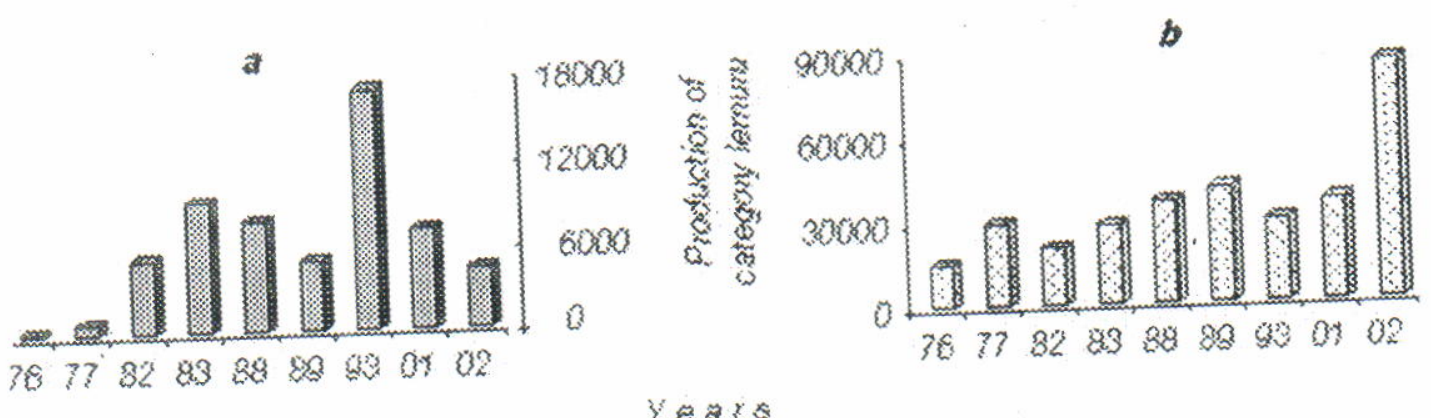

$Y \& y$

Figure 2. The development of spotted sardine production in the Java Sea. Remarks: a. catch of purse seine from Pekalongan and Juwana Landing Place; and b. Directorate General of Fisheries 
Table 2. Parameters of surplus production (Gompertz)

\begin{tabular}{cccccc}
\hline $\mathbf{B}_{\infty}$ (tons) & $\boldsymbol{r}$ & $\mathbf{C}_{\text {MSY }}$ (tons) & $\mathbf{B}_{\text {MSY }}$ (tons) & $\mathbf{E}_{\text {MsY }}$ (days) & $q\left(\times 10^{-6}\right)$ \\
\hline 65,800 & 0.77 & 18,600 & 24,200 & 30,800 & 25 \\
\hline
\end{tabular}

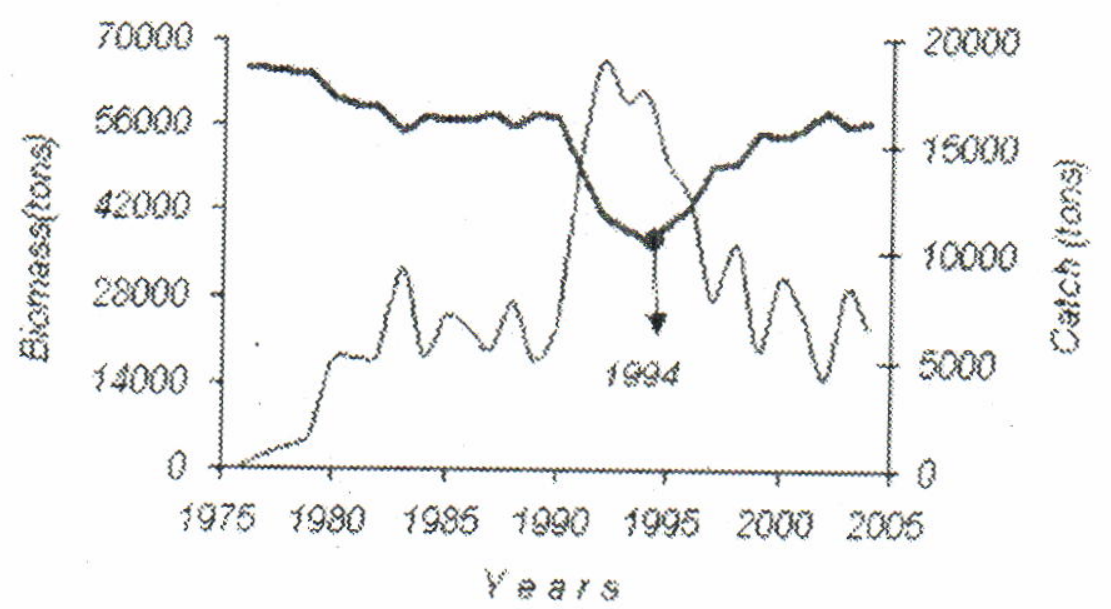

Figure 3. A biomass dynamic of $A$. sirm.

between 12,5 and $19,5 \mathrm{~cm}$ and consist of one mode only, the structure of fish population which was caught to describe more of the fish that was existed in the fishing ground rather than gear selectivity (Figure 4). It seems that is a phenomenon of missing period due to different behavior during life cycle, before spawning feeding activity decreases fisheries where fish migrate towards spawning area. Often spawning, nursery and feeding areas are different. Then, habitat selection varies according the different stage of the life cycle (life history triangle) (Bal \& Rao, 1984; King, 1998).

We perform Jones' length cohort analysis to investigate the structure of population by length classes for spotted sardine using the input data listed in Table 2 and also some value of $M(1 ; 1,64$; and 2,3 year $\left.^{-1}\right)$. Jones (1981) stated that the value of $M$ also determining the pattern of fishing mortality by length class.
Analysis can be focused on the average number at sea (survivors) and its converted value in biomass (i.e. as defined as steady state biomass). Hence, we can evaluate the pattern of yield profile and the steady state of biomass. In general, the most length size class ( $F L>15 \mathrm{~cm}$ ) shows that survivors biomass of this range size and the total biomass tend to be lower than yield, exception for the total biomass with $M=2,3$ (Table 3). Biomass-yield ratio<1 was unreasonable results, it was probably due to the highest total mortality value that was occurred in the length class of 16 until $21 \mathrm{~cm}$ (mean $Z=5,7$ until 6,8 year $^{-1}$ ).

The calculated total mortality value seems to be very high, but catch curve analysis also showed $Z$ was about 7,1 year ${ }^{-1}$ (Figure 5a). The value of $Z$ is considered as over estimation, due to very low numbers of older fish, it might be connected to emigration (Sadhotomo, 1998). He believes that source of possible bias of estimate is the spatial

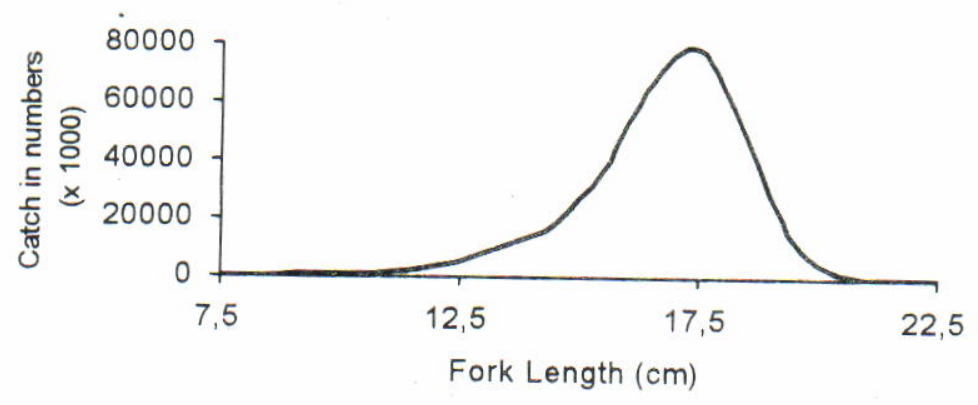

Figure 4. Structure of catch at length. 

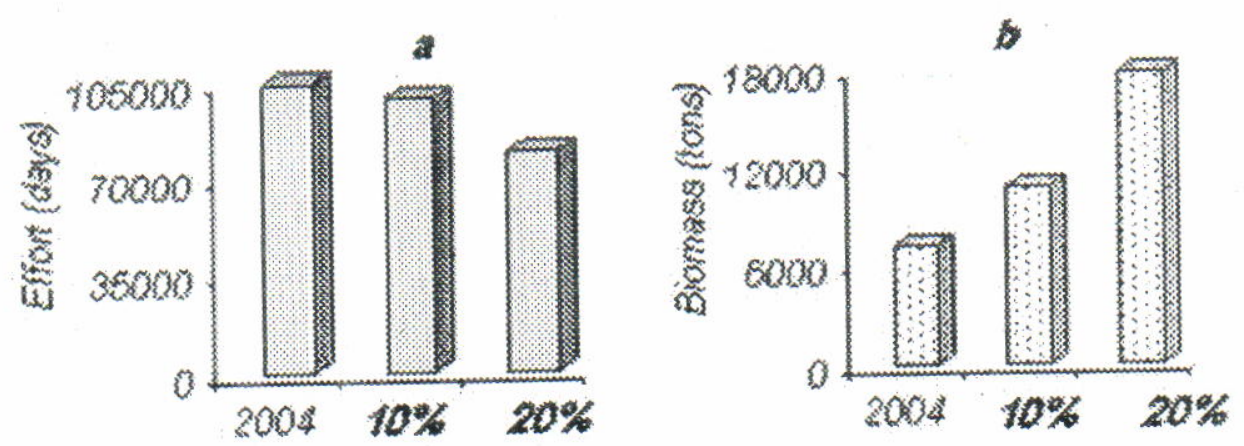

Figure 6. The reduction of effort (a) and the increasing biomass (b).

Javanese fisheries and are currently the subject of serious attention by fishery authority (Directorate General of Fisheries), and in addition effect of the high cost operation due to high price of fuel. However, we should make effective programme to manage fishing capacity and fishing tactic. Short term solution, regulation must not to freeze fishing effort and reduction of numbers of vessel; at least access restriction to the fishery for new vessels and the matter of controlling fishing tactic, especially amount of spotlight.

The most crucial is that the fisheries data base system in the area outside Java Island has not been well established yet. The current statistic data seem to be based on rough estimation with a tendency to increase every year. This activity should be organized with the institution responsible to the statistical data collection (i.e. Directorate General of Fisheries).

\section{REFERENCES}

Atmaja, S. B. 2006. Status perikanan ikan layang (Decapterus spp.) di Laut Jawa dan sekitarnya: Pendekatan dinamika biomassa dan mortalitas penangkapan. (proses diterbitkan).

Atmaja, S. B., B. Sadhotomo, \& Suwarso. 1995. Reproduction of main small pelagic species in Java Sea. In Potier and S. Nurhakim (eds): Biodynex. Seminar Biology, Dynamics, and Exploitation of small pelagic in Java Sea. Jakarta. 21 until 25 March 1994. AARD/EEC/ORSTOM. 69-84.

Atmaja, S. B. \& B. Sadhotomo. 1997. Biology of siro, Spotted sardine, Amblygater sirm, Clupeidae in the Java Sea: Some characteristics of fecundity and gonad maturity. Octopus. Vol.I (1): 100-109.
2000. Variasi geografis hasil tangkapan pukat cincin di bagian selatan Paparan Sunda. Prosiding Seminar Keanekaragaman Hayati Ikan. Pusat Studi IImu Hayati Institut Pertanian Bogor-Pusat Penelitian dan Pengembangan Biologi Lembaga IImu Pengetahuan Indonesia. 221-218.

Atmaja, S. B. \& D. Nugroho. 1995. Aspek reproduksi ikan layang deles (Decapterus macrosoma) dan siro (Amblygaster sirm) sebagai pertimbangan dalam pengelolaannya di Laut Jawa. Jurnal Penelitian Perikanan Indonesia. Vol.I (3): 1-10.

2005. Geographical distribution and status of scads population in the waters of Southern part of Sunda Shelf. Indonesian Fisheries Research Journal. Vol.11: 1-8.

2006a. Standardisasi kemampuan tangkap (koefisien q) pukat cincin di Laut Jawa dan sekitarnya dalam Perikanan pukat cincin dan sumber daya ikan pelagis kecil di bagian selatan Paparan Sunda. (proses diterbitkan).

2006b. Interaksi antara biomassa dengan upaya penangkapan: Studi kasus perikanan pukat cincin di Pekalongan dan Juwana. Jurnal Penelitian Perikanan Indonesia. Vol.12 (1): 5768.

Bal, D. V. \& K. Virabhadra Rao. 1984. Marine fisheries. Tata Mcgraw-Hill Pub. Com. Lim. New Delhi. 455 p.

Beverton R. J. H. \& Holts S. J. 1957. On the dynamics of exploited fish populations. Fish. Invest., Ser. 2. 19. London.

Clarke, R. P., S. S. Yoshimoto, \& S. G. Pooley. 1992. A bioeconomic analysis of the NorthWestern Hawaiian Islands. Lobster Fishery. Marine Resources Economics. 7 (2): 115-140. 
Conand F. 1991. Biology and phenology of Amblygaster sirm (Clupeidae) in New Caledonia, a sardine of coral environment. Bull. Mar. Sci. 48 (1): 137-149.

Dwiponggo, A., T. Hariati, S. Banon, N. L. Palomares, \& D. Pauly. 1986. Growth, mortality and recruitment of commercially important fish and penaeid shrimp in Indonesian waters. ICLARM Tech. Paper: 17. RIMF JakartaICLARM Manila.

Fauzi, A. 1999. An econometric analysis of the surplus production model and its application for Tropical Fisheries. Working paper. Institute Fisheries Analysis. Simon Fraser University. British Columbia. Canada. $19 \mathrm{p}$.

Freon, P. 1986. Introduction of environmental variables into global production models. Inst. Symp. Long Term Changes Mar. Fish. Pop. Vigo. 481-528.

Hilborn, R. \& C. J. Walters. 1992. Quantitative Fisheries Stock Assessment: Choice, Dynamics and Uncertainty. Chapman and Hall. New York. London. $570 \mathrm{p}$.

Jones, R. 1964. Estimating population size from commercial statistics when fishing mortality varies with age. Conseil Permanent
International pour l'Exploration de la Mer. Rapp.P_v. 155.

Jones, R. 1981. The use of length composition data in fish stock assessments (with notes on VPA and Cohort analysis). FAO Fish. Circ. 734. $54 \mathrm{p}$.

Pope, J. G. 1972. An investigation of the accuracy of virtual population analysis using cohort analysis. Res. Bull. Int. Comm. Norwest Atl. Fish. 9, 65-74.

Potier, M. 1998. Pêcherie de layang et senneurs semi industrie/s Javanais: Perspective historique et approche systeme. Phd Thesis. Université de Montpellier II. 280 p.

Sadhotomo, B. 1998. Bioécologie des principales espèces pélagiques exploitées en mer de Java. Phd Thesis. Université de Montpellier II. 364 p.

Sadhotomo, B. \& J. R. Durand. 1997. General Features of Java Sea Ecology. In Petit, D., P. Cotel, \& D. Nugroho (Eds.): Akustikan 2. Proceedings of acustics Seminar Akustikan 2. AARD/EEC/ORSTOM: 43-55.

Wiratno, Mudiantoro, \& A.. Fauzi. 1993. Socio economic study of fishermen in Pekalongan Regency. Fac. Eco. UNDIP. Fac. Fish. Institut Pertanian Bogor and AFSSRN. 35 p. 
